\title{
Morphology and Nitrogenase Activity of Agar Cultures and Root Nodules Formed by D-Cycloserine-resistant Mutants of Rhizobium sp. Strain 32H1
}

\author{
By C. E. PANKHURST AND A. S. CRAIG \\ Applied Biochemistry Division, Department of Scientific and \\ Industrial Research, Palmerston North, New Zealand
}

(Received 6 June 1978)

\begin{abstract}
One-step mutants of Rhizobium sp. strain $32 \mathrm{Hl}$ resistant to D-cycloserine showed substantial $(\geqslant 90 \%$ ) loss of asymbiotic (agar culture) nitrogenase activity but only partial ( 25 to $50 \%$ ) loss of symbiotic (root nodule) nitrogenase activity. Two- and three-step resistant mutants showed a further decline or complete loss of both forms of nitrogenase activity. Since D-cycloserine inhibited the uptake of alanine by the parent strain and since the mutants possessed a defective transport system for alanine, it is suggested that the mutants are unable to concentrate D-cycloserine. Agar cultures of a one-step resistant mutant contained the three morphological types of Rhizobium present in the parent culture. In contrast, only one morphological type of Rhizobium was found in cultures of two- and three-step resistant mutants. Root nodules formed by a one-step resistant mutant on cowpea contained fewer bacteroid-filled plant cells than were present in nodules formed by the parent strain. Root nodules formed by two- and three-step resistant mutants contained only a small number of infected plant cells and in many of these rhizobia had not been released from infection threads. It is suggested that changes in the permeability of the Rhizobium cell wall, resulting in resistance to $\mathrm{D}$-cycloserine, are responsible for the morphological changes and loss of nitrogenase activity in these mutants.
\end{abstract}

\section{INTRODUCTION}

Rhizobium mutants resistant to antibiotics which interfere with or inhibit bacterial cell wall/cell membrane synthesis [e.g. D-cycloserine, novobiocin, penicillin (Benveniste \& Davies, 1973)] often show loss of symbiotic effectiveness [the ability to form effective nitrogen-fixing root nodules on a suitable host legume (Schwinghamer, 1967; MacKenzie \& Jordan, 1970; Pankhurst, 1977)]. Because of this, it has been suggested that the physiological and structural integrity of the Rhizobium cell wall/cell membrane complex is important for successful nodule development (Pankhurst, 1977).

With the development of methods for the detection of nitrogenase activity in some strains of Rhizobium grown in pure culture (Keister, 1975; Pagan et al., 1975; Kurz \& La Rue, 1975; McComb et al., 1975), it is now possible to study directly the effects of antibiotic resistance on the nitrogenase activity of a Rhizobium strain. In particular, it is possible to determine whether loss of symbiotic effectiveness by antibiotic-resistant mutants of Rhizobium is also accompanied by loss of asymbiotic nitrogenase activity.

We have investigated the asymbiotic and symbiotic nitrogenase activity of mutants of Rhizobium sp. strain $32 \mathrm{H} 1$ which are resistant to D-cycloserine, an inhibitor of peptidoglycan biosynthesis in bacteria (Reitz et al., 1967). Changes in cell wall permeability resulting in decreased uptake of $\mathrm{D}$ - and L-alanine by these mutants were found to accompany loss of 
both forms of nitrogenase activity and to result in gross changes in the morphology of agar cultures and root nodules formed by the mutants.

\section{METHODS}

Mutant isolation. Rhizobium sp. strain $32 \mathrm{H} 1$, sensitive to D-cycloserine, was grown aerobically in a mannitol/salts/yeast extract $\left(\mathrm{M}^{+}\right)$medium (Pankhurst, 1977) to exponential phase, washed once in sterile $0.01 \mathrm{M}$ phosphate buffer $\left(\mathrm{pH} \mathrm{7.0)}\right.$ and diluted to give about $5 \times 10^{7}$ bacteria $\mathrm{ml}^{-1}$. Samples $(0.1 \mathrm{ml})$ were plated on the surface of $\mathrm{M}^{+}$agar containing different concentrations of D-cycloserine (Sigma). D-Cycloserine was sterilized by filtration through a sintered glass filter $(0.3 \mu \mathrm{m}$ pore size) and added to the agar medium immediately before pouring and using the agar plates. A number of one-step resistant mutants, selected from plates containing the minimum concentration of D-cycloserine which inhibited growth of the parent strain, were streaked on to $\mathbf{M}^{+}$agar without D-cycloserine and isolated colonies were transferred to $\mathbf{M}^{+}$agar slopes. In a similar manner, a number of two-step and three-step resistant mutants were isolated by plating out a mixed inoculum of, respectively, the one-step or two-step resistant mutants on to $\mathrm{M}^{+}$agar containing successively higher concentrations of $\mathrm{D}$-cycloserine. Sensitivity to $\mathrm{D}$-cycloserine was quantified in $\mathrm{M}^{+}$broth. The minimum inhibitory concentration was defined as the concentration of D-cycloserine that restricted growth to an $A_{600}$ of $0 \cdot 1$ after $72 \mathrm{~h}$.

Alanine accumulation assay. The amount of $\left[{ }^{14} \mathrm{C}\right]$ alanine concentrated by cells of strain $32 \mathrm{H} 1$ (or mutants) was established using the following procedure. The bacteria were grown in $500 \mathrm{ml} \mathrm{M}^{+}$medium until the mid-exponential phase of growth was reached. The cultures were then chilled $\left(4^{\circ} \mathrm{C}\right)$ and harvested by centrifuging at $12000 \mathrm{~g}$ for $20 \mathrm{~min}$. The cells were washed once in $0.05 \mathrm{M}$-potassium phosphate buffer $(\mathrm{pH} 8 \cdot 0)$, and then resuspended in the same buffer to give $100 \mathrm{mg}$ cells (wet wt) $\mathrm{ml}^{-1}$ and equilibrated at $25^{\circ} \mathrm{C}$. They were then preloaded with alanine by a procedure similar to that described by Reitz et al. (1967): cells were incubated for $30 \mathrm{~min}$ at $25^{\circ} \mathrm{C}$ in a mixture (total vol. $2 \mathrm{ml}$ ) containing $180 \mathrm{mg}$ cells (wet wt), $20 \mathrm{mg}$ mannitol, $2 \mu \mathrm{mol} \mathrm{D}$ - or L-alanine and $90 \mu \mathrm{mol}$ potassium phosphate buffer ( $\mathrm{pH} 8 \cdot 0$ ). After preloading, $50 \mathrm{nmol}$ D- or L-[U- $\left.{ }^{11} \mathrm{C}\right]$ alanine (The Radiochemical Centre, Amersham) was added. Samples $(200 \mu \mathrm{l})$ were removed at intervals and added to $2 \mathrm{ml} 0.05 \mathrm{M}$-potassium phosphate buffer ( $\mathrm{pH} \mathrm{8.0)}$ containing $1 \mathrm{~mm}-\mathrm{D}-$ or L-alanine held in small tubes at $0{ }^{\circ} \mathrm{C}$, to terminate uptake of the ${ }^{14} \mathrm{C}$-labelled alanine. The tubes were immediately centrifuged at $12000 \mathrm{~g}$ for $5 \mathrm{~min}$. The cells were washed with $0.05 \mathrm{M}$-potassium phosphate buffer $(\mathrm{pH} 8.0)$ at 0 to $4{ }^{\circ} \mathrm{C}$, and the pellet was resuspended in $1 \mathrm{ml}$ distilled water and transferred to a vial containing $10 \mathrm{ml}$ toluene/Triton X-100 scintillation fluid (Patterson \& Greene, 1965). Radioactivity was measured in a liquid scintillation spectrometer.

Plant nodulation tests. Cultures of strain $32 \mathrm{H} 1$ and of the $35 \mathrm{D}$-cycloserine-resistant mutants derived from strain $32 \mathrm{H} 1 \mathrm{were}$ tested for their ability to nodulate cowpea (Vigna unguiculata var. Caloona) using the methods described by Pankhurst (1977).

Nitrogenase activity. Nitrogenase activity was assayed by acetylene reduction (Hardy et al., 1968). Freshly harvested root nodules ( 100 to $200 \mathrm{mg}$ ) were placed in $15 \mathrm{ml}$ bottles fitted with screw caps containing a central hole $(3 \mathrm{~mm}$ diam.) and lined with a thick $(2.5 \mathrm{~mm})$ rubber liner. Air $(1.5 \mathrm{ml})$ was withdrawn from the bottles with a syringe and replaced with acetylene to give an acetylene concentration of $0.1 \mathrm{~atm}$. The bottles were then incubated at $25^{\circ} \mathrm{C}$. Gas samples $(0.2 \mathrm{ml})$ were removed at various times after $30 \mathrm{~min}$ and analysed for acetylene and ethylene $\left(\mathrm{C}_{2} \mathrm{H}_{4}\right)$ as described by Pankhurst \& Craig (1978).

The nitrogenase activities of agar cultures of strain $32 \mathrm{H} 1$ and of the D-cycloserine-resistant mutants of strain 32H1 were determined as described by Pankhurst \& Craig (1978).

Serology. Rabbit antiserum was prepared for strain $32 \mathrm{Hl}$ using the immunization schedule described by Dudman (1971). Antigens [100 to $200 \mathrm{mg}$ bacteria (wet wt) $\mathrm{ml}^{-1}$ ] for immunodiffusion analyses were prepared by centrifuging cultures which had been grown in $\mathbf{M}^{+}$broth and then diluted with saline $(0.14 \mathrm{M}$ $\mathrm{NaCl}$ ) to reduce their viscosity. Immunodiffusion was done as described by Dudman (1971).

Microscopy. Root nodules were prepared for light and electron microscopy by the routine method of Craig \& Williamson (1973). Agar cultures of strain $32 \mathrm{H} 1$ and of the D-cycloserine-resistant mutants of strain 32H1 were prepared for microscopy by the method of Pankhurst \& Craig (1978). 
Table 1. Minimum inhibitory concentrations of $\mathrm{D}-$ cycloserine for strain $32 \mathrm{H} 1$ and $\mathrm{D}-$ cycloserine-resistant mutants of strain $32 \mathrm{H} 1$

\begin{tabular}{|c|c|c|}
\hline Strain & $\begin{array}{l}\text { No. of } \\
\text { isolates } \\
\text { tested }\end{array}$ & $\begin{array}{l}\text { Minimum concn of } \\
\text { D-cycloserine required } \\
\text { to inhibit growth* } \\
\left(\mu \mathrm{g} \mathrm{ml}^{-1}\right)\end{array}$ \\
\hline $32 \mathrm{H} 1$ (parent) & - & 45 \\
\hline $32 \mathrm{H} 1 \mathrm{D}-\mathrm{cyc}^{\mathrm{r}}-1$ & 15 & $90(75-110)$ \\
\hline $32 \mathrm{H} 1 \mathrm{D}-\mathrm{cyc}^{\mathrm{r}}-2$ & 10 & $210(190-230)$ \\
\hline $32 \mathrm{H} 1$ D-cyc -3 & 10 & $320(280-350)$ \\
\hline
\end{tabular}

* Average value, with range of values in parentheses.

Table 2. Symbiotic effectiveness and asymbiotic nitrogenase activity of $\mathrm{D}-$ cycloserine-resistant mutants of strain $32 \mathrm{H} 1$

\begin{tabular}{|c|c|c|c|c|c|c|c|}
\hline \multirow[b]{2}{*}{ Strain } & \multirow{2}{*}{$\begin{array}{l}\text { No. of } \\
\text { isolates } \\
\text { tested }\end{array}$} & \multicolumn{3}{|c|}{$\begin{array}{l}\text { No. of isolates producing } \\
\text { the indicated nodulation } \\
\text { response on cowpea* }\end{array}$} & \multicolumn{3}{|c|}{$\begin{array}{c}\text { No. of isolates showing } \\
\text { the indicated asymbiotic } \\
\text { nitrogenase activity } \\
{\left[\text { nmol } \mathrm{C}_{2} \mathrm{H}_{4} \mathrm{~h}^{-1}{\left.\text { (culture })^{-1}\right] \dagger}^{\dagger}\right.}\end{array}$} \\
\hline & & Effective & $\begin{array}{l}\text { Partially } \\
\text { effective }\end{array}$ & Ineffective & $>20$ & $5-20$ & $<5$ \\
\hline $32 \mathrm{H} 1 \mathrm{D}-\mathrm{cyc}^{\mathrm{r}}-1$ & 15 & 2 & 11 & $2(2)$ & 3 & 10 & 2 \\
\hline $32 \mathrm{H} 1 \mathrm{D}-\mathrm{cyc}^{\mathrm{r}}-2$ & 10 & 0 & 3 & $7(4)$ & 0 & 6 & 4 \\
\hline $32 \mathrm{H} 1 \mathrm{D}-\mathrm{cyc}^{\mathrm{r}}-3$ & 10 & 0 & 0 & $10(7)$ & 0 & 3 & 7 \\
\hline
\end{tabular}

* Nodulation response was assessed visually by the appearance of plants (size, yellowness of leaves) and by dry weight measurement of plant shoots. Numbers in parentheses indicate the number of isolates showing activities of $<5 \mathrm{nmol} \mathrm{C}_{2} \mathrm{H}_{4} \mathrm{~h}^{-1}$ (culture) ${ }^{-1}$ in the asymbiotic assay.

$\dagger$ The cultures were established with an inoculum containing $5 \times 10^{7}$ bacteria $\mathrm{ml}^{-1}$, and measurements were made after $14 \mathrm{~d}$ growth at $28^{\circ} \mathrm{C}$.

\section{RESULTS}

\section{Minimum inhibitory concentrations of $\mathrm{D}$-cycloserine}

Table 1 shows the minimum inhibitory concentrations of $\mathrm{D}$-cycloserine for strain $32 \mathrm{H} 1$ and for the one-, two- and three-step D-cycloserine-resistant mutants. The minimum concentrations of D-cycloserine which allowed the selection of these three types of mutants were, respectively, 120,250 and $350 \mu \mathrm{g} \mathrm{ml}^{-1}$. The incidence of mutants resistant to these concentrations of $\mathrm{D}$-cycloserine was, in each case, about $1.5 \times 10^{-7}$.

\section{Symbiotic effectiveness and asymbiotic nitrogenase activity of $\mathrm{D}-$ cycloserine-resistant mutants}

Of $35 \mathrm{D}$-cycloserine-resistant mutants of strain $32 \mathrm{H} 1$ tested for symbiotic effectiveness on cowpea, 33 showed partial or complete loss of effectiveness (Table 2). All of these mutants also showed a marked decrease in their ability to develop asymbiotic nitrogenase activity, with many (particularly those that were ineffective) developing no activity (Table 2). The proportion of mutants showing complete loss of effectiveness and complete loss of asymbiotic nitrogenase activity increased with increasing resistance to D-cycloserine (Tables 1 and 2). All 35 mutants were serologically indistinguishable from the parent strain $32 \mathrm{H} 1$.

On the basis of these results, one mutant from each group (one-, two- and three-step resistant mutants) was selected for further study. These mutants, designated $32 \mathrm{H} 1 \mathrm{D}-\mathrm{cyc}^{\mathrm{r}}-1 / 1$, $32 \mathrm{H} 1 \mathrm{D}-\mathrm{cyc}^{\mathrm{r}}-2 / 3$ and $32 \mathrm{H} 1 \mathrm{D}-\mathrm{cyc}^{\mathrm{r}}-3 / 1$, were chosen to represent the range of symbiotic response and asymbiotic nitrogenase activity obtained. Their specific symbiotic and asymbiotic nitrogenase activities are shown in Table 3. 
Table 3. Nitrogenase activity and morphology of agar cultures and root nodules formed by strain $32 \mathrm{Hl}$ and $\mathrm{D}$-cycloserine-resistant mutants of strain $32 \mathrm{H} 1$

\begin{tabular}{|c|c|c|c|c|}
\hline & 32H1 (parent) & $32 \mathrm{H} 1$ D-cyc ${ }^{\mathrm{r}}-1 / 1$ & $32 \mathrm{H} 1 \mathrm{D}-\mathrm{cyc}^{\mathrm{r}}-2 / 3$ & $32 \mathrm{H} 1$ D-cyc ${ }^{\mathrm{r}}-3 / 1$ \\
\hline $\begin{array}{l}\text { Asymbiotic nitrogenase } \\
\text { activity [nmol } \mathrm{C}_{2} \mathrm{H}_{4} \mathrm{~h}^{-1} \\
\left.(\mathrm{mg} \text { protein })^{-1}\right]^{*}\end{array}$ & $92 \cdot 6 \pm 5 \cdot 7$ & $7 \cdot 0 \pm 1 \cdot 8$ & $0 \cdot 4 \pm 0 \cdot 1$ & 0.0 \\
\hline $\begin{array}{l}\text { Symbiotic nitrogenase activity } \\
{\left[\mathrm{nmol} \mathrm{C}_{2} \mathrm{H}_{4} \mathrm{~h}^{-1}(\mathrm{mg} \text { nodule }\right.} \\
\left.\text { fresh } \mathrm{wt})^{-1}\right]^{*}\end{array}$ & $21 \cdot 0 \pm 3 \cdot 1$ & $14 \cdot 5 \pm 3 \cdot 1$ & $2 \cdot 4 \pm 1 \cdot 2$ & 0.0 \\
\hline $\begin{array}{l}\text { Morphological type of agar } \\
\text { culture } \dagger\end{array}$ & $X$ & $\mathrm{Y}$ & $\mathrm{Z}$ & $\mathbf{Z}$ \\
\hline $\begin{array}{l}\text { Morphological type of root } \\
\text { nodule } \dagger\end{array}$ & $\mathrm{x}$ & $y$ & $y / z$ & z \\
\hline
\end{tabular}

Morphology of agar cultures formed by D-cycloserine-resistant mutants

In view of the distinctive morphology of nitrogenase-active agar cultures of strain $32 \mathrm{H} 1$ (Pankhurst \& Craig, 1978), it was of interest to examine the morphology of agar cultures of the three D-cycloserine-resistant mutants of strain 32Hl. Sections of 14-d-old agar cultures grown at $28^{\circ} \mathrm{C}$ were therefore prepared and examined by light and electron microscopy. Three types of culture morphology were found: type X (Table 3, Fig. 1a), formed by the parent strain $32 \mathrm{H} 1$; type Y (Table 3, Fig. $1 b$ ), formed by mutant $32 \mathrm{H} 1$ D-cycr-1/1; and type $Z$ (Table 3, Fig. $1 c$ ), formed by mutants $32 \mathrm{H} 1 \mathrm{D}^{\mathrm{C}} \mathrm{cyc}^{\mathrm{r}}-2 / 3$ and $32 \mathrm{H} 1$ D-cycr-3/1.

Cultures of mutant $32 \mathrm{H} 1$ D-cycr-1/1 contained a large zone of colonies with type 1 rhizobia (Pankhurst \& Craig, 1978) (Fig. 1b). Type 2 rhizobia, which are believed to be the only rhizobia in the parent $32 \mathrm{Hl}$ culture to contain nitrogenase (Pankhurst \& Craig, 1978) (Fig. 1a), were found only in small numbers in this culture. They were present at the junction of the type 1 and type 3 rhizobia (Pankhurst \& Craig, 1978) (Fig. 1b) but did not form a distinct 'band' of cells passing through colonies at a constant depth in the agar as seen in the parent $32 \mathrm{H} 1$ culture (Fig. 1 a).

Cultures of mutants $32 \mathrm{H} 1 \mathrm{D}-\mathrm{cyc}^{\mathrm{r}}-2 / 3$ and $32 \mathrm{Hl} \mathrm{D}-\mathrm{cyc}$ - $-3 / 1$, which showed little or no asymbiotic nitrogenase activity (culture type $Z$, Table 3 ), contained small colonies of rhizobia whose morphology was the same in colonies near the surface of the soft agar layer as in those near the bottom of the soft agar layer (Fig. 1c). The morphology of these rhizobia was classified as intermediate between that of typical type 1 rhizobia (with large deposits of poly- $\beta$-hydroxybutyrate) and that of typical type 3 rhizobia (with prominent nuclear material) (Pankhurst \& Craig, 1978).

\section{Morphology of root nodules formed by D-cycloserine-resistant mutants}

The morphology of root nodules formed by strain $32 \mathrm{H} 1$ and by the three D-cycloserineresistant mutants on cowpea (Vigna unguiculata) was also compared. Nodules formed by strain $32 \mathrm{H} 1$ (nodule type $\mathrm{x}$; Table 3, Fig. $2 a$ ) contained a central zone of large plant cells filled with bacteroids. Nodules formed by mutant $32 \mathrm{H} 1 \mathrm{D}-\mathrm{cyc}^{\mathrm{r}}-1 / 1$ (nodule type y; Table 3 , Fig. $2 b$ ) also contained a central zone of infected plant cells. However, the number of these cells and the number of bacteroids within them was greatly decreased (Fig. 2b). Many starch grains were found in the infected and uninfected cells of these nodules (Fig. $2 b$ ). Nodules formed by mutants $32 \mathrm{H} 1 \mathrm{D}-\mathrm{cyc}^{\mathrm{r}}-2 / 3$ and $32 \mathrm{H} 1 \mathrm{D}-\mathrm{cyc}^{\mathrm{r}}-3 / 1$ (nodule type $\mathrm{z}$; Table 3 , Fig. $2 c$ ) were ineffective and showed little or no nitrogenase activity (Table 3 ). In some of these nodules infected plant cells containing small numbers of bacteroids were found but, in 

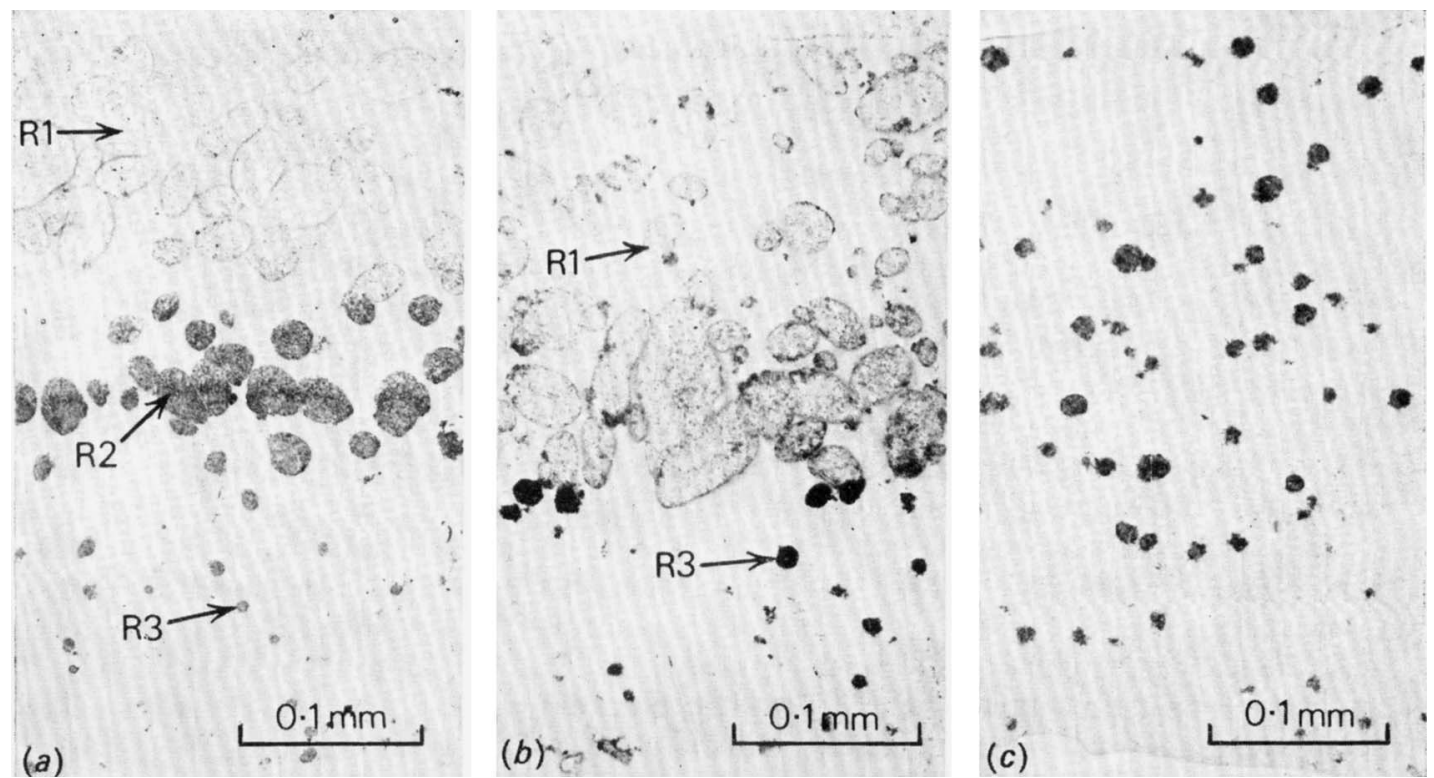

Fig. 1. Sections through the soft agar layer of 14-d-old cultures of Rhizobium sp. strain 32H1 and of two D-cycloserine-resistant mutants of strain $32 \mathrm{H} 1$. (a) Culture of strain $32 \mathrm{H} 1$ (culture type X) showing individual colonies containing rhizobia designated as type 1 (R1), type 2 (R2) and type 3 (R3) (Pankhurst \& Craig, 1978). (b) Culture of mutant 32H1 D-cyc ${ }^{\mathrm{r}}-1 / 1$ (culture type Y) showing colonies containing type 1 (R1) and type 3 (R3) rhizobia, but no band of type 2 rhizobia (cf. $a$ ). (c) Culture of mutant $32 \mathrm{H} 1 \mathrm{D}-\mathrm{cyc}^{\mathrm{r}}-3 / 1$ (culture type $\mathrm{Z}$ ) showing uniform distribution of colonies containing rhizobia classified as intermediate in morphology between type 1 and type 3 rhizobia (Pankhurst \& Craig, 1978).
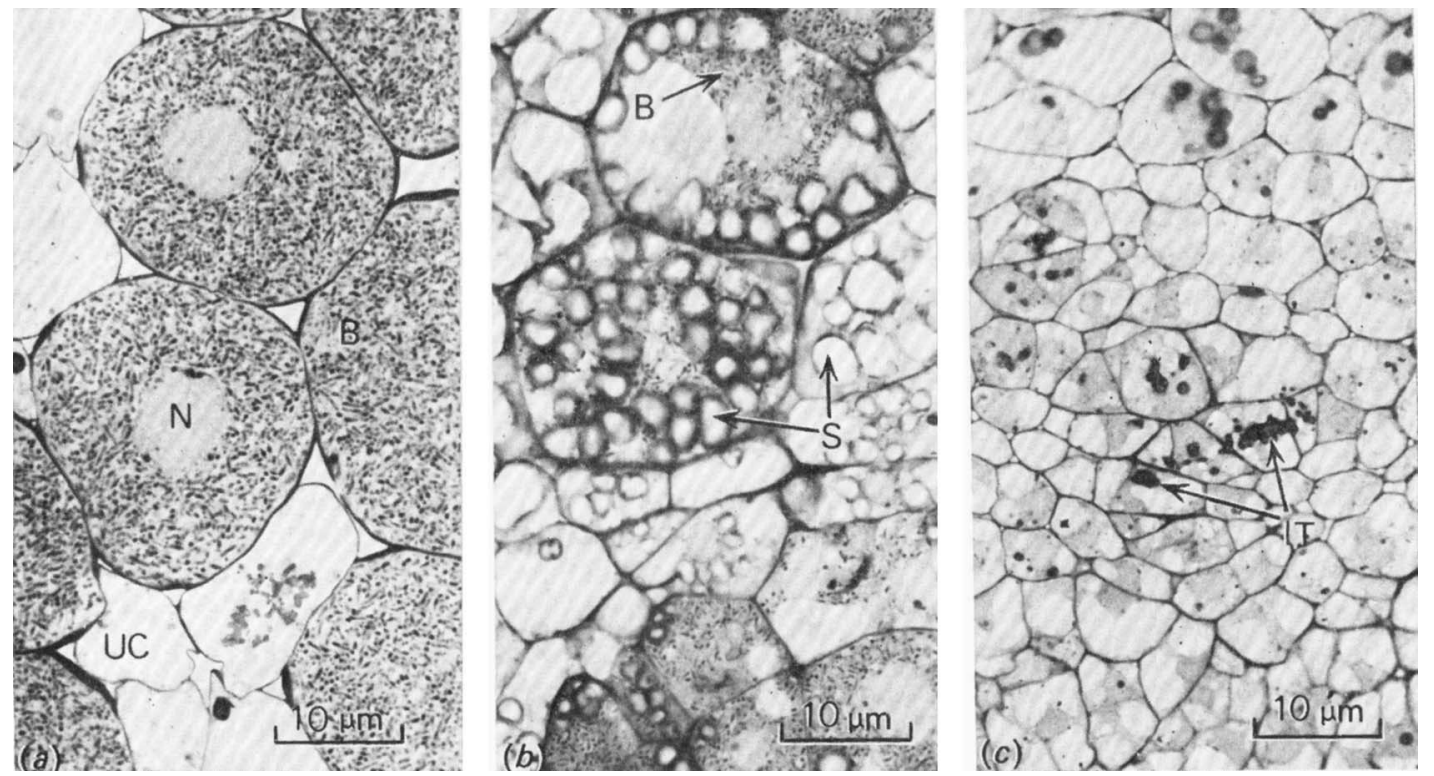

Fig. 2. Transverse sections of 28-d-old cowpea root nodules formed by Rhizobium sp. strain $32 \mathrm{H} 1$ and by two D-cycloserine-resistant mutants of strain 32H1. (a) Infected plant cells in a nodule formed by strain $32 \mathrm{H} 1$ (nodule type $\mathrm{x}$ ). These cells have a central nucleus $(\mathrm{N})$ and are filled with bacteroids (B). Many uninfected plant cells (UC) are present. (b) Infected plant cells in a nodule formed by mutant $32 \mathrm{H} 1 \mathrm{D}-\mathrm{cyc}^{\mathrm{r}}-1 / 1$ (nodule type y). These cells contain a small number of bacteroids (B) and many starch grains (S). (c) Infected plant cells in a nodule formed by mutant $32 \mathrm{H} 1 \mathrm{D}-\mathrm{Cyc}^{\mathrm{r}}-3 / 1$ (nodule type z). These cells are located in the centre of a zone of 'meristematic activity' in the nodule. They contain infection threads (IT) but no rhizobia free in their cytoplasm. 
general, the infected plant cells contained infection threads only and had no rhizobia free in their cytoplasm. The latter cells were usually located near the centre of a zone of 'meristematic activity' in the nodule (Fig. 2c).

\section{Resistance to D-cycloserine}

In view of the differences in the morphology of agar cultures and root nodules formed by strain $32 \mathrm{H} 1$ and the three $\mathrm{D}$-cycloserine-resistant mutants, it was of interest to investigate the possible mode of resistance of the mutants to D-cycloserine. D-Cycloserine is reported to be concentrated by the alanine transport system in Streptococcus faecalis (Reitz et al., 1967) and Escherichia coli (Curtiss et al., 1965; Wargel et al., 1971). We therefore examined the uptake of $\mathrm{D}$ - or $\mathrm{L}-\left[{ }^{14} \mathrm{C}\right]$ alanine by strain $32 \mathrm{H} 1$ and the three $\mathrm{D}$-cycloserine-resistant mutants. All three mutants showed decreased rates of uptake of both D- and L-alanine compared with the parent strain (Table 4). With mutant 32H1 D-cycr-1/1, the initial rates of D- and L-alanine uptake were $50 \%$ and $40 \%$ of the parent values, respectively. With mutants $32 \mathrm{H} 1 \mathrm{D}-\mathrm{cyc}^{\mathrm{r}}-2 / 3$ and $32 \mathrm{H} 1 \mathrm{D}-\mathrm{cyc}^{\mathrm{r}}-3 / 1$, the uptake rates were even lower, being about $50 \%$ of those for mutant $32 \mathrm{H} 1 \mathrm{D}-\mathrm{cyc}^{\mathrm{r}}-1 / 1$. In all experiments, the amount of D- or L-alanine accumulated was proportional to time (within the limits of a $15 \mathrm{~min}$ assay). To minimize possible secondary reactions, the initial rates of uptake (presented in Table 4) were established during short time intervals $(2 \mathrm{~min}$ ) in preloaded cells (see Methods). D-Alanine (1 mM) decreased the uptake of $\mathrm{L}_{\mathrm{L}}\left[{ }^{14} \mathrm{C}\right]$ alanine $(1 \mathrm{mM})$ and $\mathrm{L}$-alanine $(1 \mathrm{mM})$ decreased the uptake of $\mathrm{D}-\left[{ }^{14} \mathrm{C}\right]$ alanine $(1 \mathrm{~mm})$, indicating that $\mathrm{D}$-alanine and $\mathrm{L}$-alanine enter strain $32 \mathrm{H} 1$ by the same transport system. In a similar fashion, D-cycloserine (1 $\mathrm{mm})$ decreased the uptake of both $\mathrm{D}-\left[{ }^{14} \mathrm{C}\right]$ alanine and $\mathrm{L}-\left[{ }^{14} \mathrm{C}\right]$ alanine (Table 4).

\section{DISCUSSION}

Acquisition of D-cycloserine resistance by Rhizobium sp. strain $32 \mathrm{H} 1$ was associated with loss of the ability of this strain to develop both asymbiotic (agar culture) and symbiotic (root nodule) nitrogenase activity. The extent of this loss was associated with the level of resistance to the antibiotic. One-step resistant mutants showed substantial ( $\geqslant 90 \%)$ loss of asymbiotic nitrogenase activity but only partial ( 25 to $50 \%$ ) loss of symbiotic nitrogenase activity. Two- and three-step resistant mutants, which were four and seven times more resistant to D-cycloserine than the parent strain (Table 1), showed a further decline or a complete loss of both forms of nitrogenase activity.

Two mechanisms of resistance to D-cycloserine are known for bacteria. The first, reported for D-cycloserine-resistant mutants of Escherichia coli (Curtiss et al., 1965; Wargel et al., 1971) and Streptococcus faecalis (Reitz et al., 1967) involves a decrease in the permeability of the cell wall to the antibiotic due to defective functioning of the D- and L-alanine transport system. The second, found in some D-cycloserine-resistant mutants of $S$. faecalis (Reitz et al., 1967), involves an increase in the activities of two enzymes selectively inhibited by $\mathrm{D}$-cycloserine, namely alanine racemase and D-alanylalanine synthetase. Although only the former mechanism was investigated in this work, all three D-cycloserine-resistant mutants tested showed a significant decrease in their ability to concentrate D- and L-alanine. As $\mathrm{D}$-cycloserine inhibited the uptake of both $\mathrm{D}$ - and $\mathrm{L}$-alanine in the parent strain, resistance to D-cycloserine is probably due to the inability of the mutants to concentrate the antibiotic.

The progressive loss of both forms of nitrogenase activity with increasing resistance to D-cycloserine was also reflected in the morphology of the agar cultures and root nodules developed by the mutants (Table 3). Agar cultures of the one-step resistant mutant $32 \mathrm{H} 1$ D-cycr-1/1 contained the three morphological types of rhizobia present in the parent strain culture (Pankhurst \& Craig, 1978). In contrast, agar cultures of the two- and three-step 


\section{Table 4. Initial rates of accumulation of $\mathrm{D}-\left[{ }^{14} \mathrm{C}\right]$ alanine and $\mathrm{L}-\left[{ }^{14} \mathrm{C}\right]$ alanine by strain $32 \mathrm{H} 1$ and $\mathrm{D}-$ cycloserine-resistant mutants of strain $32 \mathrm{H} 1$}

The alanine accumulation assay was done with $1 \mathrm{mM}-\mathrm{D}-\left[{ }^{14} \mathrm{C}\right]$ alanine or $1 \mathrm{mM}-\mathrm{L}-\left[{ }^{14} \mathrm{C}\right]$ alanine, and $180 \mathrm{mg}$ bacteria (wet wt). Other additions were made to the assay system as indicated.

\author{
Additions to assay system \\ D- $\left[{ }^{11} \mathrm{C}\right]$ Alanine \\ None (complete system) \\ Sodium azide $(30 \mathrm{~mm})$ \\ $\mathrm{D}$-Cycloserine (1 mM) \\ L-Alanine (1 mM) \\ L- $\left[{ }^{14} \mathrm{C}\right]$ Alanine \\ None (complete system) \\ Sodium azide $(30 \mathrm{~mm})$ \\ D-Cycloserine (1 mM) \\ D-Alanine (1 mM)
}

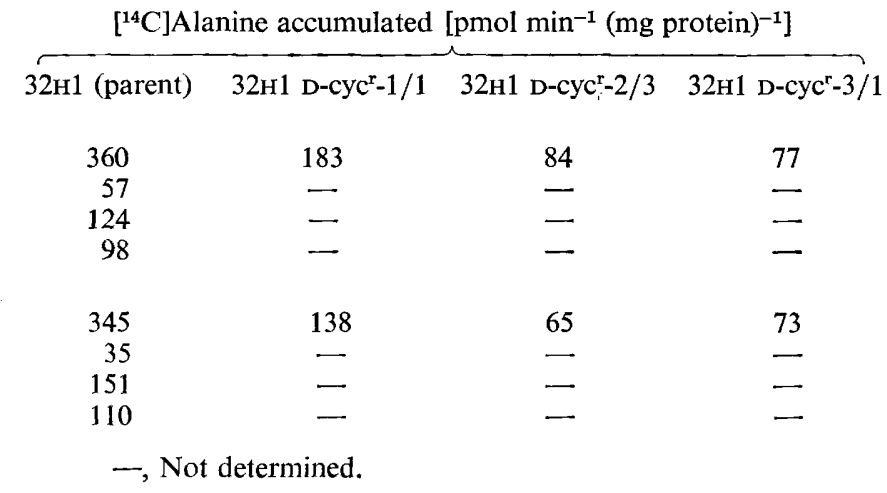

resistant mutants, which had little or no nitrogenase activity, contained only one morphological type. These observations were paralleled by a decrease in the proportion of infected plant cells containing bacteroids in nodules formed by the one-step resistant mutant and by failure of rhizobia to be released from infection threads in nodules formed by the two- and three-step resistant mutants. As changes in the cell wall/cell membrane complex are thought to occur when rhizobia are transformed into nitrogen-fixing bacteroids in the nodule (Bergersen, 1974; van Brussel et al., 1977) and when strain 32H1 transforms into a pleiomorphic 'putative nitrogen-fixing form' in agar culture (Pankhurst \& Craig, 1978), it seems likely that, if resistance to D-cycloserine involves a change in the permeability of the Rhizobium cell wall, this could interfere with these transformations and affect the development of nitrogenase activity.

Simultaneous loss of asymbiotic and symbiotic nitrogenase activity has also been reported for two out of five mutants of $R$. japonicum strain 61A76 (Maier \& Brill, 1976) and for two out of 40 nitrate reductase deficient mutants of strain 32H1 (Pagan et al., 1977). The mutants isolated by Maier \& Brill (1976) may be defective in nitrogenase synthesis, but those isolated by Pagan et al. (1977) show that disruption of other processes within Rhizobium may also affect its ability to develop nitrogenase activity. In a similar fashion, we suggest that changes in the permeability of the Rhizobium cell wall resulting in resistance to D-cycloserine alter the ability of Rhizobium to develop nitrogenase activity.

We wish to thank Miss P. A. Mundt for technical assistance, Mr I. D. Simpson for help in the preparation of the photographs and Dr M. J. Boland for help with the alanine accumulation assay.

\section{REFERENCES}

Benveniste, R. \& Davies, J. (1973). Mechanisms of antibiotic resistance in bacteria. Annual Review of Biochemistry 42, 471-506.

Bergersen, F. J. (1974). Formation and function of bacteroids. In The Biology of Nitrogen Fixation, pp. 474-495. Edited by A. Quispel. Amsterdam: North-Holland Publishing Co.

Brussel, A. A. N. van, Planqué, K. \& Quispel, A. (1977). The wall of Rhizobium leguminosarum in bacteroid and free-living forms. Journal of General Microbiology 101, 51-56.
Craig, A. S. \& Wrlliamson, K.I. (1973). Three inclusions of rhizobia bacteroids and their cytochemical character. Archiv für Mikrobiologie 87, 165-171.

Curtiss, R., Charamella, L. J., Berg, C. M. \& HARRIS, P. E. (1965). Kinetic and genetic analyses of D-cycloserine inhibition and resistance in Escherichia coli. Journal of Bacteriology 90, 1238-1250.

Dudman, W. F. (1971). Antigenic analysis of Rhizobium japonicum by immunodiffusion. $A p$ plied Microbiology 21, 973-985. 
Hardy, R. W. F., Holsten, R. D., Jackson, E. K. \& BURNS, R. C. (1968). The acetylene-ethylene assay for $\mathrm{N}_{2}$ fixation: laboratory and field evaluation. Plant Physiology 43, 1185-1207.

KeISTER, D. L. (1975). Acetylene reduction by pure cultures of rhizobia. Journal of Bacteriology 123, 1265-1268.

Kurz, W. G. W. \& La Rue, T. A. (1975). Nitrogenase activity in rhizobia in absence of plant host. Nature, London 256, 407-408.

MacKenzie, C. R. \& Jordan, D. C. (1970). Cell wall phospholipid and viomycin resistance in Rhizobium meliloti. Biochemical and Biophysical Research Communications 40, 1008-1012.

MAIER, R. J. \& BRILL, W. J. (1976). Ineffective and non-nodulating mutant strains of Rhizobium japonicum. Journal of Bacteriology 127, 763-769.

MсСомв, J. A., Elliott, J. \& Dilworth, M. J. (1975). Acetylene reduction by Rhizobium in pure culture. Nature, London 256, 409-410.

Pagan, J. D., Child, J. J., Scowcroft, W. R. \& Gibson, A. H. (1975). Nitrogen fixation by Rhizobium cultured on a defined medium. Nature, London 256, 406-407.

Pagan, J. D., Scowcroft, W. R., Dudman, W. F. \& Gibson, A. H. (1977). Nitrogen fixation in nitrate reductase-deficient mutants of cultured rhizobia. Journal of Bacteriology 129, 718-723.
Pankhurst, C. E. (1977). Symbiotic effectiveness of antibiotic-resistant mutants of fast- and slowgrowing strains of Rhizobium nodulating Lotus species. Canadian Journal of Microbiology 23, 1026-1033.

Pankhurst, C. E. \& Craig, A. S. (1978). Effect of oxygen concentration, temperature and combined nitrogen on the morphology and nitrogenase activity of Rhizobium sp. strain $32 \mathrm{H} 1$ in agar culture. Journal of General Microbiology 106, 207-219.

Patterson, M. S. \& Greene, R. G. (1965). Measurement of low energy beta-emitters in aqueous solution by liquid scintillation counting of emulsions. Analytical Chemistry 37, 854-857.

Reitz, R. H., Slade, H. D. \& Neuhaus, F. C. (1967). The biochemical mechanisms of resistance by streptococci to the antibiotics D-cycloserine and $O$-carbamyl-D-serine. Biochemistry 6, 2561-2570. Schwinghamer, E. A. (1967). Effectiveness of Rhizobium as modified by mutation for resistance to antibiotics. Antonie van Leeuwenhoek 33, 121-136.

Wargel, R. J., Shadur, C. A. \& Neuhaus, F. C. (1971). Mechanism of D-cycloserine action: transport mutants for $\mathrm{D}$-alanine, $\mathrm{D}$-cycloserine, and glycine. Journal of Bacteriology 105, 10281035 . 